\title{
Correction to: Epigenetic tuning of brain signal entropy in emergent human social behavior
}

Meghan H. Puglia ${ }^{1,2^{*}}$, Kathleen M. Krol ${ }^{1,3}$, Manuela Missana ${ }^{3,4}$, Cabell L. Williams' ${ }^{1}$ Travis S. Lillard ${ }^{1}$, James P. Morris ${ }^{1}$, Jessica J. Connelly ${ }^{1+}$ and Tobias Grossmann ${ }^{1,3+}$

\section{Correction to: BMC Med 18, 244 (2020) https://doi.org/10.1186/s12916-020-01683-x}

Following the publication of the original article [1], the following errors in Figs. 1 and 6 were brought to our attention:

1. The curves were inadvertently omitted from the graph in Fig. 1.

2. The colour bar in Fig. 6 appeared blank in the published article.

The correct figures are presented here below:

\section{Author details}

'Department of Psychology, University of Virginia, Charlottesville, VA 22904 USA. ${ }^{2}$ Department of Neurology, University of Virginia, P.O. Box 800834, Charlottesville, VA 22908, USA. ${ }^{3}$ Max Planck Institute for Human Cognitive and Brain Sciences, 04103 Leipzig, Germany. ${ }^{4}$ Department of Early Child Development and Culture, Leipzig University, 04109 Leipzig, Germany.

Published online: 12 September 2020

\section{Reference}

1. Puglia $\mathrm{MH}$, et al. Epigenetic tuning of brain signal entropy in emergent

human social behavior. BMC Med. 2020;18:244 https://doi.org/10.1186/ s12916-020-01683-x.

The original article can be found online at https://doi.org/10.1186/s12916020-01683-x

* Correspondence: meghan.puglia@virginia.edu

†Jessica J. Connelly and Tobias Grossmann contributed equally to this work.

'Department of Psychology, University of Virginia, Charlottesville, VA 22904,

USA

2Department of Neurology, University of Virginia, P.O. Box 800834,

Charlottesville, VA 22908, USA

Full list of author information is available at the end of the article

C The Author(s). 2020 Open Access This article is licensed under a Creative Commons Attribution 4.0 International License, which permits use, sharing, adaptation, distribution and reproduction in any medium or format, as long as you give appropriate credit to the original author(s) and the source, provide a link to the Creative Commons licence, and indicate if changes were made. The images or other third party material in this article are included in the article's Creative Commons licence, unless indicated otherwise in a credit line to the material. If material is not included in the article's Creative Commons licence and your intended use is not permitted by statutory regulation or exceeds the permitted use, you will need to obtain permission directly from the copyright holder. To view a copy of this licence, visit http://creativecommons.org/licenses/by/4.0/ The Creative Commons Public Domain Dedication waiver (http://creativecommons.org/publicdomain/zero/1.0/) applies to the data made available in this article, unless otherwise stated in a credit line to the data. 


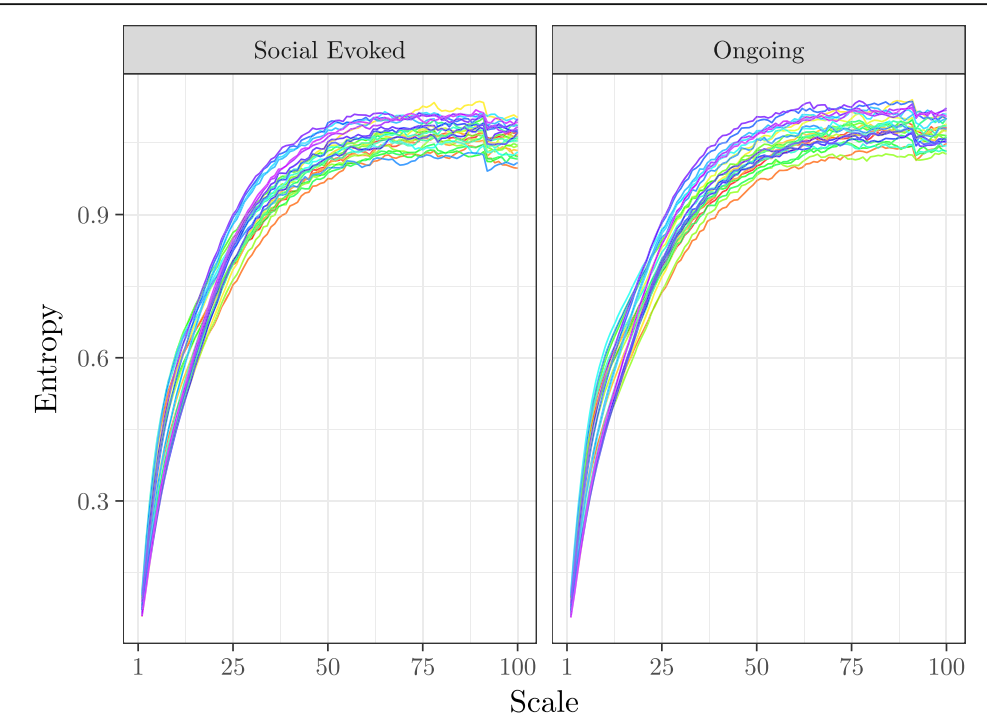

Electrode

- FP1 - $\mathrm{C} 4$

$-\mathrm{FP} 2-\mathrm{T} 8$

- F9 - TP9

$-\mathrm{F} 7-\mathrm{CP} 5$

$-\mathrm{F} 3-\mathrm{CP} 6$

$-\mathrm{FZ}-\mathrm{TP} 10$

$-\mathrm{F} 4-\mathrm{P} 7$

$-\mathrm{F} 8-\mathrm{P} 3$

$-\mathrm{F} 10-\mathrm{PZ}$

$-\mathrm{FC} 5-\mathrm{P} 4$

$-\mathrm{FC} 6-\mathrm{P} 8$

$-\mathrm{T} 7-\mathrm{O} 1$

$-\mathrm{C} 3-\mathrm{O} 2$

Fig. 1

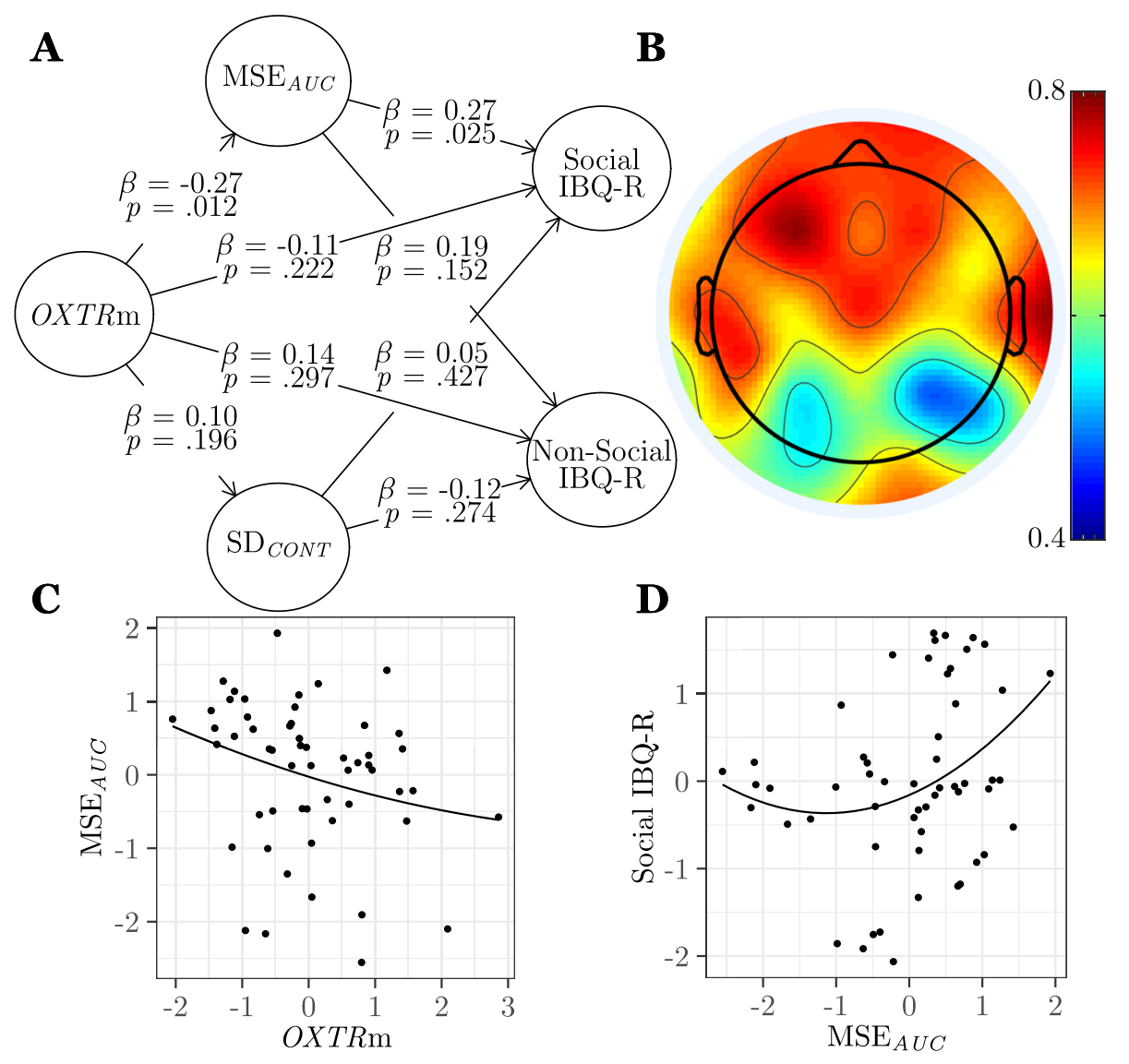

Fig. 6 